\title{
Application of a plant-tissue composition in combination with the use of an aerosol of an electrochemical activated solution of neutral anolyte in the association of respiratory tract infections and wound infections of the distal extremities of cattle
}

\author{
Anatoly Alekseev, Olga Petrova*, Vera Usevich, Mikhail Barashkin, and Igor Milstein \\ Ural State Agrarian University, Yekaterinburg, Russia
}

\begin{abstract}
Bovine respiratory infections occupy the second place in the nosological picture after diseases of the digestive system and cause huge economic damage, which in the Russian Federation, according to our estimates, amounts to several billion rubles a year. Very often, respiratory pathologies in highly productive cows are complicated by wound infections of the distal extremities, which primarily include necrobacteriosis, streptococcosis and staphylococcosis, which also bring economic losses to farms due to reduced animal productivity and culling of highly productive cows. The primary causecontributing to the development of wound infections of the distal extremities in cattle is respiratory infections. According to our long-term observations, all farms where outbreaks of necrobacteriosis were recorded were unfavorable for bovine respiratory infections, such as infectious rhinotracheitis (IRT), viral diarrhea(VD), parainfluenza type 3 (PG-3) and respiratory syncytial infection (RSI). Comprehensive prevention of wound infectionsof the dental extremities of cattle (cattle) should include mandatory prevention of respiratory infections. For complex prevention of mixed infection, we proposed the use of an ECHO (electrochemically activated) solution of neutral anolyte $(\mathrm{ANK}+)$ in the form of a fine aerosol in combination with the use of a plant-tissue preparation "Vidoral", (Patent RU 2,625,022 C2 dated 11.07.2017, copyright holder of the Federal State Budgetary Institution of Higher Education of the UralState Agrarian University ) with immunomodulatory properties.
\end{abstract}

\section{Introduction}

Bovine respiratory infections occupy the second place in the nosological picture after diseases of the digestive system [2] and cause huge economic damage, which in the Russian Federation, according to our estimates, amounts to several billion rubles per year. Very

\footnotetext{
* Corresponding author: super.kafedra2013@yandex.ru
} 
often, respiratory pathologies in highly productive cows are complicated by wound infections of the distal extremities, which primarily include necrobacteriosis, streptococcosis and staphylococcosis, which also bring economic losses to farms due to reduced animal productivity and culling of highly productive cows. [3, 5, 6,14]

We determined the relationship between these seemingly completely different infections and the mechanism of their association. When the respiratory tract is affected, hypoxia occurs in the animal body, which leads to endogenous intoxication, leading to rumen acidosis $[1,4]$. As a result of acidosis, blood flow in the microcirculatory bed is disrupted, in cattle, the vessels of the distal extremities are primarily affected, which leads to a violation of the trophic skin of the limbs and hooves, laminitis develops. Damaged hooves are the gateway of infection for the causative agents of necrobacteriosis Fusobacterium necrophorum, Staphylococcosis Staphylococcus spp., Streptococcus spp. and other pathogens. In addition, favorable conditions for the development of mixed infection are created by reducing the overall resistance of the body, both in respiratory pathology and in pathology of the distal extremities. [3, 6]

Thus, the primary cause contributing to the development of wound infections of the distal extremities in cattle is respiratory infections. According to our long-term observations, all farms in which outbreaks of necrobacteriosis were recorded were unfavorable for bovine respiratory infections, such as IRT, VD, PG-3 and RSI.

Comprehensive prevention of wound infections of the distal extremities of cattle should include mandatory prevention of respiratory infections.

\section{Materials and methods of research}

Epizootological, clinical, bacteriological, biochemical, and hematological methods of research were used.

The antimicrobial efficacy анолитаof neutral anolyte (ANK+) was evaluated at the Sverdlovsk Regional Veterinary Laboratory.

To assess the antimicrobial efficacy анолитаof neutral anolyte $(\mathrm{ANK}+)$, museum strains of bacterial cultures were used: Escherichia coli ATCC 25922, Salmonella typhimurium, Enterococcus faecalis ATCC 29212, Proteus mirabilis No. 3177 , Listeria monocytogenes, Staphylococcus aureus ATCC 6538 -P, Pseudomonas aeruginosa CCM 1960.

To obtain a reliable result, laboratory tests were carried out in accordance with the current and current regulatory documentation in the laboratory.

Biochemical studies were carried out according to current methods currently used in veterinary laboratories.

Evaluation of the specific effectiveness of a plant-tissue immunomodulator "Vidoral"(patent No. RU 2,625,022 dated 14.07.2015 ofthe Federal State Budgetary Educational Institution of Higher Education of the Ural State Agrarian University) was conducted in accordance with the" Rules for Preclinical studies of the safety and effectiveness of pharmacological substances"," Guidelines for the experimental (Preclinical) study of new Pharmacological Substances", methodological guidelines for determining the safety and effectiveness of biological active food additives.

Statistical processing of digital data was performed using standard Microsoft Word and Excel application programs, including calculating the average values $(\mathrm{M})$, the average error $(\mathrm{m})$, and the standard deviation of the sample $(\sigma)$ on a PC.

\section{Results and discussion}

For complex prevention of mixed infection, we proposed the use of an ECHO 
(electrochemically activated) solution of neutral anolyte (ANK + ) in the form of a fine aerosol in combination with the use of a plant-tissue preparation "Vidoral", (Patent RU 2,625,022 C2 dated 11.07.2017, copyright holder of the Federal State Budgetary Institution of Higher Education of the UralState Agrarian University ) with immunomodulatory properties.

The advantage of aerosol application of neutral anolyte (ANK+) is that fine aerosol is able to get into the deeper parts of the respiratory tract when inhaled and there exert its bactericidal and virucidal effect. [8, 9, 10, 11,15]

The antimicrobial efficacy of neutral anolyte $(\mathrm{ANK}+)$ was evaluated at the Sverdlovsk Regional Veterinary Laboratory.

To assess the antimicrobial efficacy of neutral anolyte $(\mathrm{ANK}+)$, museum strains of bacterial cultures were used: Escherichia coli ATCC 25922, Salmonella typhimurium, Enterococcus faecalis ATCC 29212, Proteus mirabilis No. 3177 , Listeria monocytogenes, Staphylococcus aureus ATCC 6538 -P, Pseudomonas aeruginosa CCM 1960.

To obtain a reliable result, laboratory tests were carried out in accordance with the current and current regulatory documentation in the laboratory.

To determine the antimicrobial effect, methods for determining bactericidal efficiency were used: a qualitative test, a quantitative test, antimicrobial activity in solid forms was determined, and theantimicrobial activity of the drug in relation to water was determined. [7]

A quality test. The marker culture for non-cancerous and non-spore-forming bacteria is Escherichia coli. For a qualitative test, strains of Escherichia coli bacterial cultures were taken colito determine the bactericidal activity against gram-negative bacteria Salmonella typhimurium, Proteus mirabilis and Pseudomonas aeruginosa. The marker test culture for determining the bactericidal activity against spore microflora is Staphylococcus aureus, in addition for gram-positive bacteria, strains of Listeria monocytogenes and Enterococcus faecalis cultures were taken to check the effect on gram-positive bacteria Listeria monocytogenеs и Enterococcus faecalis.

From each bacterial culture was prepared A one-billion-pound suspension based on $0.9 \%$ saline solution was prepared from each bacterial culture, according to the optical turbidity standard No. $10\left({ }^{109} \mathrm{CFU} / \mathrm{cm}^{3}\right)$, after which $0.5 \mathrm{ml}$ of the resulting suspension of each culture was added to $4.5 \mathrm{ml}$ of anolyte. To decontaminate the suspension, the exposure was maintained for 5 minutes. The resulting solution of suspension and neutral anolyte $(\mathrm{ANK}+)$ after exposure in the amount of $0.5 \mathrm{ml}$ was added to $4.5 \mathrm{ml}$ of neutralizer. To neutralize the neutral anolyte $(\mathrm{ANK}+)$, the exposure was kept for 5 minutes.

The resulting processed material was sown on meat-peptone broth (MPB) and meatpeptone agar (MPA). Media with inoculation were thermostated at a temperature of $37^{\circ \circ} \mathrm{C}$, and the growth of microorganisms was recorded after 24 and 48 hours.

To control the growth of the culture anolyte, neutral anolyte (ANK +$)$ was replaced with sterile distilled water. To control the sterility of media and solutions, bacterial test cultures were replaced with sterile distilled water.

Table 1. Quality test results.

\begin{tabular}{|c|c|c|c|c|c|c|c|}
\hline & \multicolumn{10}{|c|}{ Test-culture } \\
\cline { 2 - 9 } & $\begin{array}{c}\text { Escherichi } \\
\text { a coli }\end{array}$ & $\begin{array}{c}\text { Salmonell } \\
\text { a } \\
\text { typhimuri } \\
\text { um }\end{array}$ & $\begin{array}{c}\text { Enterococ } \\
\text { cus } \\
\text { faecalis }\end{array}$ & $\begin{array}{c}\text { Listeria } \\
\text { monocyto } \\
\text { genes }\end{array}$ & $\begin{array}{c}\text { Proteus } \\
\text { mirabilis }\end{array}$ & $\begin{array}{c}\text { Staphyloc } \\
\text { occus } \\
\text { aureus }\end{array}$ & $\begin{array}{c}\text { Pseudomo } \\
\text { nas } \\
\text { aeruginos } \\
\text { a }\end{array}$ \\
\cline { 2 - 10 } & $\begin{array}{c}\text { Accountin } \\
\text { g time, } \\
\text { hour. }\end{array}$ & $\begin{array}{c}\text { Accountin } \\
\text { g time, } \\
\text { hour. }\end{array}$ & $\begin{array}{c}\text { Accountin } \\
\text { g time, } \\
\text { hour. }\end{array}$ & $\begin{array}{c}\text { Accountin } \\
\text { g time, } \\
\text { hour. }\end{array}$ & $\begin{array}{c}\text { Accountin } \\
\text { g time, } \\
\text { hour. }\end{array}$ & $\begin{array}{c}\text { Accountin } \\
\text { g time, } \\
\text { hour. }\end{array}$ & $\begin{array}{c}\text { Accountin } \\
\text { g time, } \\
\text { hour. }\end{array}$ \\
\cline { 2 - 11 }
\end{tabular}




\begin{tabular}{|l|c|c|c|c|c|c|c|c|c|c|c|c|c|}
\hline $\begin{array}{l}\text { Neutral } \\
\text { anolyte } \\
\text { (ANC+) }\end{array}$ & - & - & - & - & - & - & - & - & - & - & - & - & - \\
\hline $\begin{array}{l}\text { Monitoring } \\
\text { the sterility of } \\
\text { media }\end{array}$ & - & - & - & - & - & - & - & - & - & - & - & - & - \\
\hline $\begin{array}{l}\text { Crop growth } \\
\text { control }\end{array}$ & + & + & + & + & + & + & + & + & + & + & + & + & + \\
\hline
\end{tabular}

As a result of the qualitative test, it can be concluded that neutral anolyte $(\mathrm{ANK}+)$ has a high bactericidal activity with a short exposure time in high dilutions, both against grampositive and gram-negative bacteria. [8, 9, 10, 11,13]

Quantitative test. Strains of Escherichia coli bacterial cultures were taken for a qualitative test Escherichia coli, and to determine the bactericidal activity against gramnegative bacteria Salmonella typhimurium, Proteus mirabilis and Pseudomonas aeruginosa. The marker test culture for determining the bactericidal activity against spore microflora is Staphylococcus aureus, in additionна грамположительные бактерии, strains of Listeria monocytogenes and Enterococcus faecalis cultures were taken to check the effect on grampositive bacteria Listeria monocytogenе и Enterococcus faecalis.

From each bacterial culture was prepared A one-billion-pound suspension based on $0.9 \%$ saline solution was prepared from each bacterial culture, according to the optical turbidity standard No. $10\left({ }^{109} \mathrm{CFU} / \mathrm{cm}^{3}\right)$, after which $0.5 \mathrm{ml}$ of the resulting suspension of each culture was added to $4.5 \mathrm{ml}$ of neutral anolyte $(\mathrm{ANK}+)$. To decontaminate the suspension, the exposure was maintained for 5 minutes. The resulting solution of suspension and neutral anolyte (ANK + ) after exposure in the amount of $0.5 \mathrm{ml}$ was added to $4.5 \mathrm{ml}$ of neutralizer. To neutralize the neutral anolyte $(\mathrm{ANK}+)$, the exposure was kept for 5 minutes.

The treated material in the amount of $1 \mathrm{ml}$ was transferred to a Petri dish, $12 \mathrm{ml}$ of molten MPA was poured, cooled to $45^{\circ \circ} \mathrm{C}$. The contents of the cup were thoroughly mixed. After agar solidification, the cups were thermostated at $37^{\circ \circ} \mathrm{C}$. Colony growth was recorded after 48 and 72 hours.

To control the sterility of the media, molten MPA was poured into a cup with sterile distilled water. To control air contamination, two open Petri dishes with MPA and milk-salt agar (MSA) were used at 20 minutes of exposure.

Table 2. Results of the quantitative test.

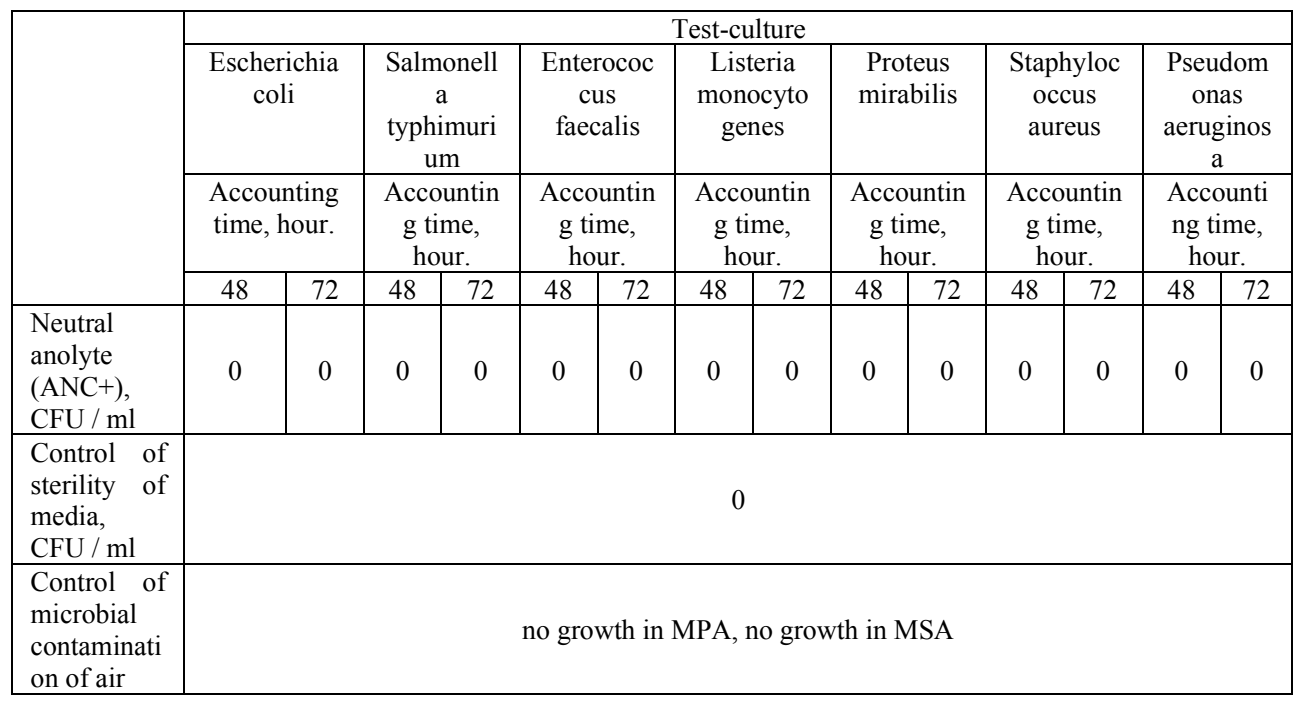


Based on the results of the quantitative test, it can be concluded that neutral anolyte $(\mathrm{ANK}+)$ has a high bactericidal activity against both gram-positive and gram-negative bacteria.

Determination of antimicrobial activity in solid forms. The marker culture for noncancerous and non-spore-forming bacteria is Escherichia coli For a qualitative test, strains of Escherichia coli bacterial cultures were taken colito determine the bactericidal activity against gram-negative bacteria Salmonella typhimurium, Proteus mirabilis and Pseudomonas aeruginosa. The marker test culture for determining the bactericidal activity against spore microflora is Staphylococcus aureus, in additionнa gram-positive bacteria, strains of Listeria monocytogenes and Enterococcus faecalis cultures were taken to check the effect on gram-positive bacteria Listeria monocytogenes и Enterococcus faecalis.

From each bacterial culture was prepared A one-billionth suspension based on $0.9 \%$ saline solution was prepared from each bacterial culture, according to the optical turbidity standard No. $10\left({ }^{109} \mathrm{CFU} /{ }^{\mathrm{cm} 3}\right)$. For the experiment, Petri dishes were taken with preprepared wells in MPA. The culture suspension was applied to the agar surface with a spatula, and Petri dishes were placed in a thermostat at $37^{\circ} \mathrm{C}$ to dry ${ }^{\text {the cultures. }} \mathrm{C}$ and was kept for 10 minutes. анолитNeutral anolyte $(\mathrm{ANC}+)$ was introduced into the well in such a way that it did not come into contact with the applied culture and did not spill over the edges of the well.

The cups were thermostated at a temperature $37 \mathrm{C}$ during the day. To control the experiment, culture growth control, medium sterility control, and air contamination control were performed. To control growth, no neutral anolyte $(\mathrm{ANK}+)$ was added to the plate with the applied bacterial culture. To control the sterility of the media, no bacterial test culture was applied to the agar. To control air contamination, two open Petri dishes with MPA and MSA were used for 20-minute exposure.

Table 3. Determination of antimicrobial activity of anolyte in solid forms.

\begin{tabular}{|c|c|c|c|c|c|c|c|}
\hline & \multicolumn{7}{|c|}{ Test-culture } \\
\hline & $\begin{array}{l}\text { Escherich } \\
\text { ia coli }\end{array}$ & $\begin{array}{l}\text { Salmonell } \\
\text { a } \\
\text { typhimuri } \\
\text { um }\end{array}$ & $\begin{array}{c}\text { Enterococ } \\
\text { cus } \\
\text { faecalis }\end{array}$ & $\begin{array}{l}\text { Listeria } \\
\text { monocyto } \\
\text { genes }\end{array}$ & $\begin{array}{l}\text { Proteus } \\
\text { mirabilis }\end{array}$ & $\begin{array}{l}\text { Staphyloc } \\
\text { occus } \\
\text { aureus }\end{array}$ & $\begin{array}{l}\text { Pseudomo } \\
\text { nas } \\
\text { aeruginos } \\
\text { a }\end{array}$ \\
\hline & $\begin{array}{l}\text { Accountin } \\
\text { g time, } \\
\text { hour. }\end{array}$ & $\begin{array}{l}\text { Accountin } \\
\text { g time, } \\
\text { hour. }\end{array}$ & $\begin{array}{l}\text { Accountin } \\
\text { g time, } \\
\text { hour. }\end{array}$ & $\begin{array}{l}\text { Accountin } \\
\text { g time, } \\
\text { hour. }\end{array}$ & $\begin{array}{l}\text { Accountin } \\
\text { g time, } \\
\text { hour. }\end{array}$ & $\begin{array}{l}\text { Accountin } \\
\text { g time, } \\
\text { hour. }\end{array}$ & $\begin{array}{l}\text { Accountin } \\
\text { g time, } \\
\text { hour. }\end{array}$ \\
\hline & 24 & 24 & 24 & 24 & 24 & 24 & 24 \\
\hline $\begin{array}{l}\text { АнолитNeutr } \\
\text { al anolyte } \\
(\mathrm{ANC}+)\end{array}$ & 24 & 21 & 25 & 23 & 21 & 23 & 20 \\
\hline $\begin{array}{l}\text { Control of } \\
\text { sterility of } \\
\text { media }\end{array}$ & - & - & - & - & - & - & - \\
\hline $\begin{array}{l}\text { Crop growth } \\
\text { control }\end{array}$ & + & + & + & + & + & + & + \\
\hline $\begin{array}{l}\text { Contaminatio } \\
\text { nand air } \\
\text { control }\end{array}$ & \multicolumn{7}{|c|}{ no increase in MPA, no increase in MSA } \\
\hline
\end{tabular}

To take into account the antimicrobial activity анолитаof neutral anolyte (ANK+), zones of inhibition of the growth of microorganisms sensitive to the action of anolyte were measured. It can be concluded that the anolyte has a high bactericidal activity against a wide range of pathogens of bacterial diseases. The use of neutral anolyte $(\mathrm{ANK}+)$ as a bactericidal preparation is effective, including for multi-resistant microorganisms.

Determination of the antimicrobial activity of anolyte to BGCP in an aqueous medium. To determine the antimicrobial activity, a bacterial culture was taken-a marker for non- 
cocci and неспорообразующих бактерий non-spore-forming Escherichia coli bacteria coliof the ATCC 25922 strain.

From each bacterial culture was prepared A one-billion-pound suspension based on $0.9 \%$ saline solution was prepared from the culture, according to the optical turbidity standard No. $10\left({ }^{109} \mathrm{CFU} / \mathrm{cm}^{3}\right)$.

2 flasks with a capacity of $1000 \mathrm{~cm} 3$ were used for the experiment ${ }^{3}$. Flasks filled ${ }^{\text {with }} 900$ $\mathrm{cm}^{\mathrm{c}}$ of water, pretreated with a suspension of test cultures in the amount $\mathrm{t}^{\mathrm{of} 0.1 \mathrm{~cm} 3}$, were treated with neutral anolyte $(\mathrm{ANK}+)$ in the ratio of 1 part aof neutral anolyte $(\mathrm{ANK}+)$ to 9 parts of water. One flask was kept at an exposure of 30 minutes, the second 60 minutes. The treated water was examined for the presence of BGCP by the method of membrane filters.

A filter disk was installed in the funnel of the filter unit, then a sample was poured in a volume $^{\text {of } 300 \mathrm{~cm} 3}$ and passed through this filter disk. The filter, without turning it over, was transferred to Petri dishes with Endo differential diagnostic nutrient medium with flambed tweezers. The cups were incubated in a thermostat at $37^{\circ \circ} \mathrm{C}$, the results were recorded after 24 hours, with no growth after 48 hours.

Water not treated with neutral anolyte $(\mathrm{ANK}+)$ was used as a control. To control air contamination, two open Petri dishes with MPA and MSA were used for 20-minute exposure.

Table 4. Determination of antimicrobial activity of neutral anolyte $(\mathrm{ANK}+)$ in relation to $\mathrm{BGCP}$ in the aquatic environment

\begin{tabular}{|c|c|c|c|c|c|l|}
\hline \multirow{2}{*}{ Test culture } & \multirow{2}{*}{$\begin{array}{c}\text { Accounting } \\
\text { time, hour. }\end{array}$} & \multicolumn{3}{|c|}{$\begin{array}{c}\text { Neutral anolyte } \\
\text { (ANC+) }\end{array}$} & \multicolumn{4}{c|}{ Monitoring } & \\
\cline { 3 - 6 } & & $\begin{array}{c}30 \\
\text { minutes }\end{array}$ & $\begin{array}{c}60 \\
\text { minutes }\end{array}$ & $\begin{array}{c}30 \\
\text { minutes }\end{array}$ & $\begin{array}{c}60 \\
\text { minutes }\end{array}$ & control of air \\
\hline \multirow{2}{*}{$\begin{array}{c}\text { Escherichia } \\
\text { coli ATCC } \\
25922\end{array}$} & 24 & - & - & + & + & $\begin{array}{l}\text { MPA growth } \\
\text { is absent } \\
\text { MSA growth } \\
\text { is absent }\end{array}$ \\
\cline { 2 - 6 } & 48 & - & - & + & + \\
\hline
\end{tabular}

Studies of the antimicrobial activity of neutral anolyte (ANK+) in relation to BGCP in an aqueous medium have shown that the drug does not lose its bactericidal properties when decontaminating large volumes of liquid material and is also a universal antimicrobial drug not only because of the wide spectrum of action, but also because of the possibility of decontamination of various types of objects.

Evaluation of the effectiveness of using anolyte neutral $(\mathrm{ANK}+)$ aerosols in combination with a plant-tissue preparation "Vidoral" for the prevention of acute respiratory viral infections and diseases of the distal extremities of cattle.

The experiment was conducted in one of the livestock farms of the Ural-Siberian region that was not affected by SARS (IRT, RSI, VD-BS, PG-3), staphylococcosis, streptococcosis and necrobacteriosis. Fusobacterium necrophorum, Staphylococcus epidermidis and Streptococcus zooepidemicus were isolated from sick animals in the farm epidermidis и Streptococcus zooepidemicus.

For the experiment, 4 groups were formed - two groups of 6-month-old calves (experimental group No. 1 and control group No. 1) with 10 heads in each group and two groups of 2-lactation cows (experimental group No. 2 and control group No. 2) with 10 heads in each group.

The conditions for feeding, keeping and caring for animals of the experimental and control groups were identical.

The animals of the experimental groups were exposed to a fine aerosol of the preparation anolyte neutral $(\mathrm{ANK}+)$ sprayed during aerosol treatment in a room, the animals of the experimental groups were in another room. 
Cows of experimental group No. 2 and control group No. 2 were given the vaccine against necrobacteriosis of cattle limbs inactivated associated "Nekovak", in accordance with the instructions for the use of the vaccine, cows of experimental group No. 2 were subcutaneously injected with the drug for 5 days "Vidoral" in a dose of $0.025 \mathrm{ml} / \mathrm{kg}$ of live weight.

Blood from calves of experimental group No. 1 and control group No. 2 was taken for research before the experiment and after 20 days. Blood for the study was taken from cows of experimental group No. 2 and control group No. 2 before the start of the work experience and 15 days after the end of the course "Vidorala".

The aerosol was sprayed, in the presence of animals, in a ventilated room using an aerosol sprayer "Ultraspreer R-60M" (produced by Raster LLC, Moscow Yekaterinburg). The drug consumption was $300 \mathrm{ml} / \mathrm{m}^{2}$.

Changes in microbial contamination of the environment were evaluated by flushing from the surfaces of walls and floors. Flushes were performed before treatment and after treatment at an exposure of 30 minutes. The quality of air treatment was determined by precipitation in Petri dishes with meat peptone agar (MPA). For this purpose, Petri dishes with MPA were placed for 15 minutes at an exposure of 15 minutes, 30 minutes and 6 hours. [7, 11, 12, 16]

Table 5. Evaluation of the effectiveness of surface treatment with anolyte using an aerosol sprayer "R-60M Ultraspreer»

\begin{tabular}{|l|l|c|c|}
\hline Surfaces & $\begin{array}{l}\text { Microbiological } \\
\text { indicator }\end{array}$ & \multicolumn{2}{|c|}{ Number of microorganisms, thousand ${ }^{/ \mathrm{m} 3}, \mathrm{CFU}$} \\
\cline { 3 - 4 } & & Before processing & $\begin{array}{c}\text { After processing at } 30 \\
\text { minutes of exposure }\end{array}$ \\
\hline \multirow{2}{*}{ Floor } & CMAFAnM & $280 \pm 13.4$ & $70 \pm 1.2^{*}$ \\
\cline { 2 - 4 } & Mold & Content $5 \pm 0.2$ & 0 \\
\hline \multirow{2}{*}{ Walls } & CMAFAnM walls & $86 \pm 0.1$ & $12 \pm 0.3^{*}$ \\
\cline { 2 - 4 } & Mold & $10 \pm 0.9$ & $2^{*}$ \\
\hline
\end{tabular}

*The data is accurate. $\mathrm{P} \leq 0.05$

As can be seen from the results presented in Table 5, after treatment with a fine aerosol of neutral anolyte $(\mathrm{ANK}+)$ with an exposure of 30 minutes, the amount of CMAFAnM on the floor decreased by 4 times, on the wall by 7.17 times, the amount of mold on the floor decreased to zero, on the wall by 5 times, which indicates the effectiveness of the treatment.

Table 6. Evaluation of the effectiveness of air treatment with anolyte neutral (ANK+) using an aerosol sprayer "R-60M Ultraspreer»

\begin{tabular}{|l|c|c|c|c|}
\hline \multirow{2}{*}{$\begin{array}{l}\text { Microbiological } \\
\text { indicator }\end{array}$} & \multicolumn{4}{|c|}{ Number of microorganisms, thousand ${ }^{\mathrm{m} 3}$, CFU } \\
\cline { 2 - 5 } & $\begin{array}{c}\text { Before } \\
\text { processing }\end{array}$ & $\begin{array}{c}\text { After 15 } \\
\text { minutes of } \\
\text { exposure }\end{array}$ & $\begin{array}{c}\text { After 30 } \\
\text { minutes of } \\
\text { exposure }\end{array}$ & $\begin{array}{c}\text { After 6 } \\
\text { hours of } \\
\text { exposure }\end{array}$ \\
\hline KMAFAnM & $366 \pm 12,3$ & $165 \pm 1,4^{*}$ & $82 \pm 1,18$ & $4 \pm 0,7^{*}$ \\
\hline Molds & $15 \pm 1,3$ & $5 \pm 0,6$ & $2 \pm 0,4^{*}$ & 0 \\
\hline
\end{tabular}

*The data is accurate. $\mathrm{P} \leq 0.05$

The results in table 6 show that at an exposure of 15 minutes, the number of Kmafanm in the air decreased by 2.2 times, the mold 3 times, at an exposure of 30 minutes number Kmafanm decreased 4.46 times, mold is 7.5 times of the original level exposure 6 hours, the number of Kmafanm decreased by 91.5 time, the number of mold is down to zero.

Assessment of the effect of anolyte aerosol on calves was carried out by changes in hematological and biochemical parameters of blood. Blood from animals was taken for research before the experiment and after 20 days. 
Table 7. Influence анолитаof neutral anolyte aerosol (ANK+) on the hematological parameters of calves.

\begin{tabular}{|c|c|c|c|c|c|}
\hline \multirow[b]{2}{*}{ Indicator } & \multirow[b]{2}{*}{$\begin{array}{l}\text { The } \\
\text { norm }\end{array}$} & \multicolumn{2}{|c|}{ Before the experience } & \multicolumn{2}{|c|}{ After the experience } \\
\hline & & $\begin{array}{l}\text { Experimental } \\
\text { group No. } 1\end{array}$ & $\begin{array}{c}\text { Control group } \\
\# 1\end{array}$ & $\begin{array}{l}\text { Experimental } \\
\text { group No. } 1\end{array}$ & $\begin{array}{l}\text { Control } \\
\text { group \# } 1\end{array}$ \\
\hline $\begin{array}{l}\text { Red blood } \\
\text { cells, }{ }^{10-12} / 1\end{array}$ & $5,-7,5$ & $7,0 \pm 1,3$ & $7,3 \pm 0,5$ & $8,5 \pm 0,6^{*}$ & $7,6 \pm 0,5$ \\
\hline Hemoglobin, g / 1 & $90-120$ & $112 \pm 17,5$ & $106 \pm 4,4$ & $118 \pm 2,5$ & $108 \pm 5,3$ \\
\hline Platelets, ${ }^{109} / 1$ & $\begin{array}{l}100- \\
800\end{array}$ & $454,9 \pm 12,8$ & $457,3 \pm 18,1$ & $532,2 \pm 12,8^{*}$ & $498,5 \pm 13,1$ \\
\hline $\begin{array}{l}\text { White blood } \\
\text { cells, }{ }^{109} / 1\end{array}$ & $4,5-12$ & $8,7 \pm 1,4$ & $8,9 \pm 2,2$ & $8,8 \pm 1,3$ & $8,6 \pm 2,8$ \\
\hline $\begin{array}{l}\text { Lymphocytes, } \\
109 / 1\end{array}$ & $2,5-7,5$ & $6,5 \pm 1,01$ & $6,2 \pm 1,0$ & $6,6 \pm 1,6$ & $6,3 \pm 1,2$ \\
\hline ESR, $\mathrm{mm} / \mathrm{h}$ & $0,5-1,0$ & $0,92 \pm 0,1$ & $0,91 \pm 0,3$ & $0,95 \pm 0,2$ & $0,98 \pm 0,1$ \\
\hline
\end{tabular}

*The data is accurate. $\mathrm{P} \leq 0.05$

As can be seen from Table 7, the number of red blood cells in experimental group No. 1 increased by $21.4 \%$, hemoglobin by $5.4 \%$, and in control group No. 1 by $4.1 \%$ and $1.9 \%$, respectively. It can be assumed that the aerosol application of the drug anolyte neutral $(\mathrm{ANK}+)$ has a stimulating effect on erythropoiesis. The remaining parameters varied within the limits of physiological variability, which indicates the absence of a toxic effect with aerosol use of the drug.

Table 8. Influence of neutral anolyte aerosol (ANK+) on the biochemical parameters of calves ' blood.

\begin{tabular}{|c|c|c|c|c|c|}
\hline \multirow[b]{2}{*}{ Indicator } & \multirow[b]{2}{*}{ The norm } & \multicolumn{2}{|c|}{ Before the experience } & \multicolumn{2}{|c|}{ After the experience } \\
\hline & & $\begin{array}{c}\text { Experimental } \\
\text { group No. } 1\end{array}$ & $\begin{array}{c}\text { Control } \\
\text { group \# } 1\end{array}$ & $\begin{array}{c}\text { Experimental } \\
\text { group No. } 1\end{array}$ & $\begin{array}{c}\text { Control } \\
\text { group \# 1 }\end{array}$ \\
\hline Total protein, $\mathrm{g} / \mathrm{l}$ & $70-82$ & $65,5 \pm 4,7$ & $66,5 \pm 5,5$ & $66,8 \pm 2,0$ & $66,1 \pm 3,46$ \\
\hline Urea, $\mathrm{mmol} / \mathrm{l}$ & 2 to 5,5 & $3,4 \pm 0,6$ & $3,2 \pm 0,5$ & $2,5 \pm 0,8$ & $3,4 \pm 0,4$ \\
\hline Calcium, $\mathrm{mmol} / 1$ & $2,2-3,1$ & $3,6 \pm 0,1$ & $3,3 \pm 0,4$ & $3,0 \pm 0,2$ & $2,9 \pm 0,2$ \\
\hline $\begin{array}{l}\text { Phosphorus, } \\
\mathrm{mmol} / \mathrm{l}\end{array}$ & $1,4-2,8$ & $2,9 \pm 0,3$ & $2,5 \pm 0,3$ & $2,8 \pm 0,4$ & $2,2 \pm 0,3$ \\
\hline ALT, Ed./1 & $7-35$ & $6,4 \pm 8,47$ & $5,5 \pm 9,98$ & $2,1 \pm 0,2$ & $4,4 \pm 0,8$ \\
\hline AST, IU./1 & $45-101$ & $70,1 \pm 3,94$ & the $61.8 \pm 1,7$ & $70,8 \pm 2,5$ & $78,6 \pm 1,6$ \\
\hline
\end{tabular}

*The data is accurate. $\mathrm{P} \leq 0.05$

In the experimental group No. 1 to the start of the experiment the content of calcium was higher than the physiological norm, at the end of the experience, it decreased by $16.7 \%$ to physiological limits, the content of urea in the blood serum decreased by $26.5 \%$, ALT to $67.1 \%$, indicating that normalization of mineral metabolism, of the liver and kidneys, while in the control group No. 1 calcium concentration decreased by $12.1 \%$, ALT is $20 \%$, the content of urea increased by $6.2 \%$. The remaining parameters varied within the limits of physiological variability, which indicates the absence of a toxic effect with aerosol application of anolyte.

During the experiment, 3 calves of the control group No. 1 showed clinical signs of acute respiratory viral infections. In experimental group No. 1, due to an increase in the overall resistance of the calves ' body, diseases of the respiratory tract of viral etiology were not detected. 
Table 9. Effect of aerosol treatment with neutral anolyte (ANK+) on the incidence of acute respiratory viral infections in calves.

\begin{tabular}{|l|c|c|}
\hline Indicator & Experimental group No. 1 & Control group No. 1 \\
\hline Sick calves, heads & 0 & 3 \\
\hline ARVI incidence, \% & 0 & 30 \\
\hline
\end{tabular}

As can be seen from Table 9, no acute respiratory viral infections were registered in the experimental group No. 1, while in the control group No. 1, the incidence of acute respiratory viral infections was $30 \%$.

Table 10. Effect of a plant-tissue preparation "Vidoral" on the hematological parameters of calves.

\begin{tabular}{|l|c|c|c|c|c|}
\hline \multirow{2}{*}{\multicolumn{1}{|c|}{ Indicator }} & \multirow{2}{*}{$\begin{array}{c}\text { The } \\
\text { norm }\end{array}$} & \multicolumn{2}{|c|}{ Before the experience } & \multicolumn{2}{c|}{ After the experience } \\
\cline { 3 - 6 } & $\begin{array}{c}\text { Experimental } \\
\text { group }\end{array}$ & Control group & $\begin{array}{c}\text { Experimental } \\
\text { group }\end{array}$ & Control group \\
\hline $\begin{array}{l}\text { Red blood cells, } \\
\text { mln/1 }\end{array}$ & $5,-7,5$ & $5,71 \pm 1,32$ & $5,67 \pm 0,46$ & $5,93 \pm 1,21$ & $5,79 \pm 1,32$ \\
\hline Hemoglobin, g\% & & $9,69 \pm 0,55$ & $9,67 \pm 1,44$ & $11,58 \pm 1,53^{*}$ & $9,68 \pm 1,93$ \\
\hline $\begin{array}{l}\text { White blood } \\
\text { cells, }{ }^{109} / 1\end{array}$ & $4,5-12$ & $7,69 \pm 1,41$ & $7,75 \pm 1,12$ & $1,80 \pm 1,39^{*}$ & $3,50 \pm 2,78$ \\
\hline $\begin{array}{l}\text { Total protein, g/ } \\
1\end{array}$ & & $4,81 \pm 1,01$ & $4,67 \pm 1,05$ & $4,67 \pm 1,86$ & $4,5 \pm 1,92$ \\
\hline
\end{tabular}

*The data is accurate. $\mathrm{P} \leq 0.05$

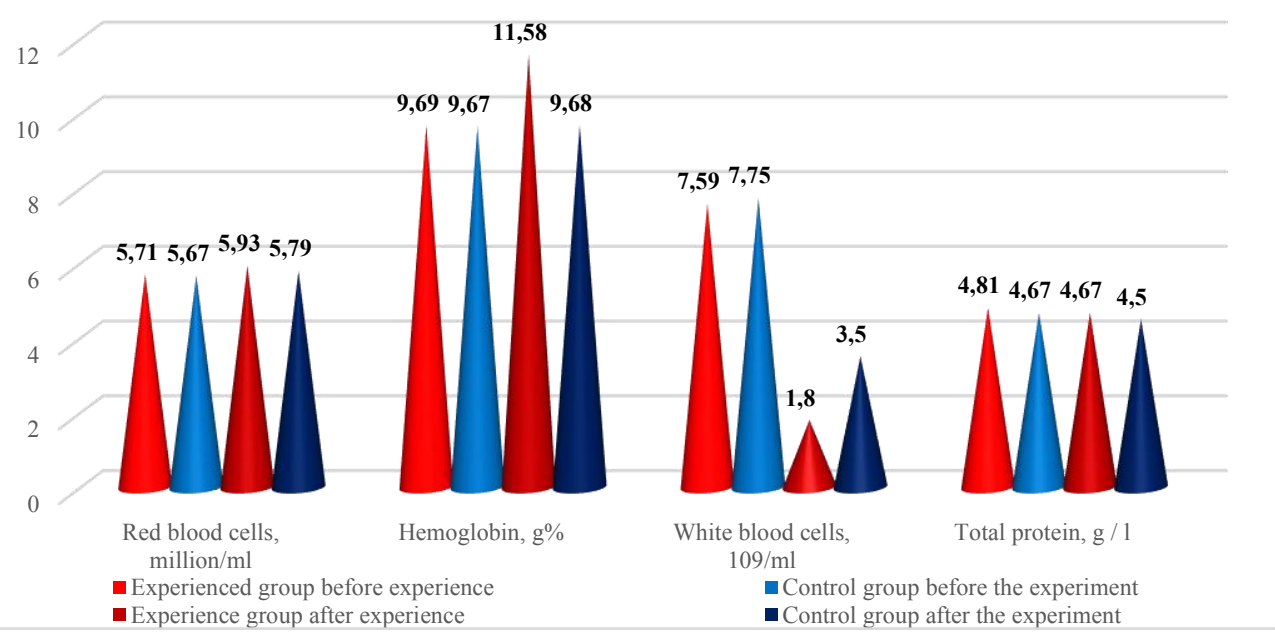

Fig. 1. Effect of the drug "Vidoral" on the hematological parameters of cattle.

As can be seen from the data presented in Figure 1, the number of red blood cells in the blood of cows in the experimental group increased by $3.9 \%$, in the control group by $2.1 \%$, the hemoglobin concentration in the experimental group increased by $19.5 \%$, which indicates an increase in erythropoiesis, the number of white blood cells decreased by $76.3 \%$, which is a sign of a decrease in inflammatory reactions in the body of cows.

The titers of antibodies in the blood serum of cows to Fusobacterium necrophorum, Staphylococcus epidermidis and Streptococcus zooepidemicus were studied. 
Table 11. Effect of neutral anolyte aerosol $(\mathrm{ANK}+)$ in combination with a plant-tissue preparation "Vidoral" on the intensity of cow immunity to necrobacteriosis.

\begin{tabular}{|l|c|c|}
\hline \multirow{2}{*}{ Group } & \multicolumn{2}{|c|}{ Titers to Fusobacterium necrophorum, $\log _{2}$} \\
\cline { 2 - 3 } & before the experiment & after the experiment \\
\hline Experimental group 2 & 3 & 9 \\
\hline Control group 2 & 3 & 3 \\
\hline
\end{tabular}

*The data is accurate. $\mathrm{P} \leq 0.05$

Table 12. Effect of neutral anolyte aerosol $(\mathrm{ANK}+)$ in combination with a plant-tissue preparation "Vidoral" on seroconversion of cows to streptococcosis and staphylococcosis.

\begin{tabular}{|l|c|c|c|c|}
\hline \multirow{2}{*}{ group } & \multicolumn{2}{|c|}{$\begin{array}{c}\text { Titers for Staphylococcus } \\
\text { epidermidis, } \log _{2}\end{array}$} & \multicolumn{2}{c|}{$\begin{array}{c}\text { Titles for Streptococcus } \\
\text { zooepidemicus, } \log _{2}\end{array}$} \\
\cline { 2 - 5 } & $\begin{array}{c}\text { before } \\
\text { experience }\end{array}$ & $\begin{array}{c}\text { after } \\
\text { experience }\end{array}$ & $\begin{array}{c}\text { before } \\
\text { experience }\end{array}$ & $\begin{array}{c}\text { after } \\
\text { experience }\end{array}$ \\
\hline Experimental group 2 & 2 & 8 & 2 & 7 \\
\hline Control group 2 2 & 2 & 2 & 2 & 2 \\
\hline
\end{tabular}

*The data is accurate. $\mathrm{P} \leq 0.05$

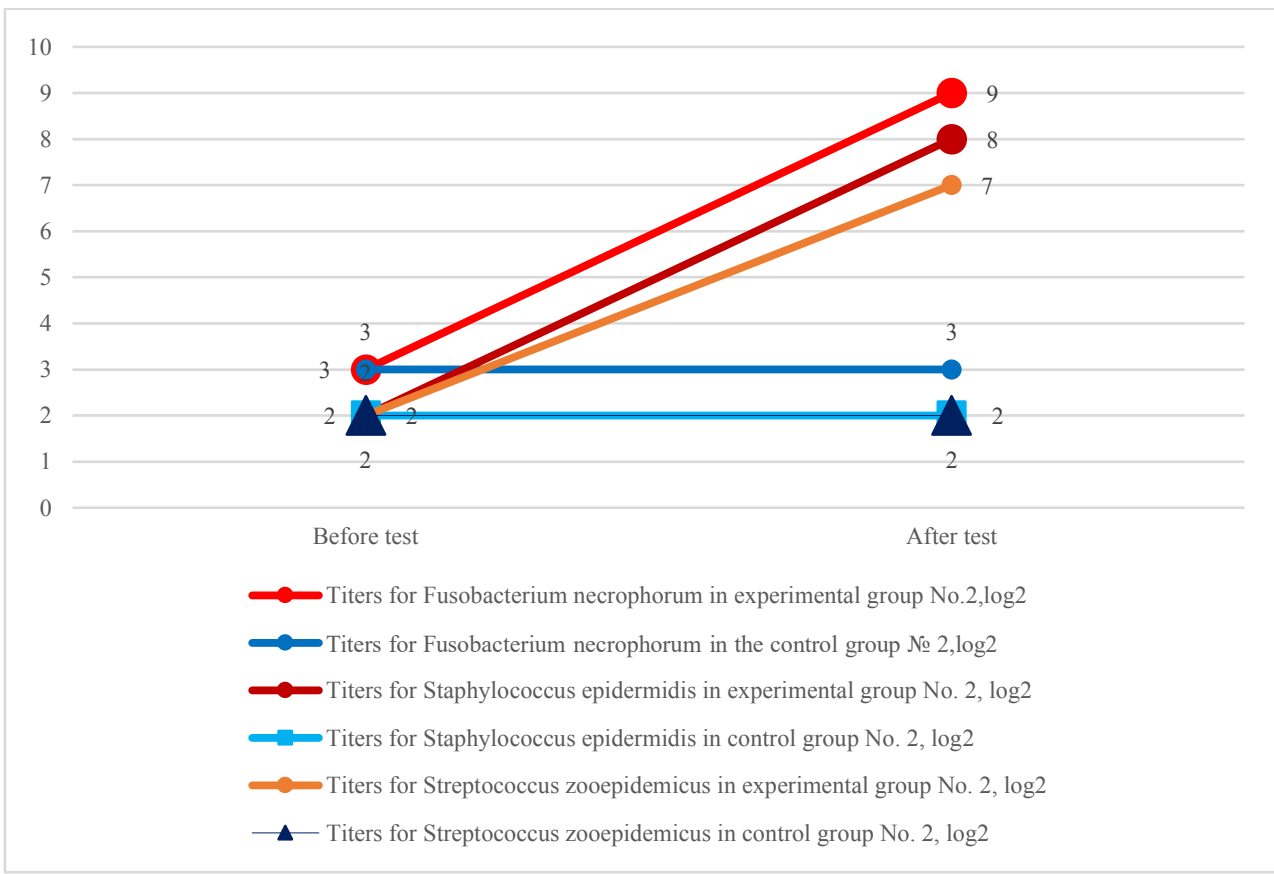

Fig. 2. Effect of neutral anolyte (ANK + ) when used together with a plant-tissue preparation "Vidoral" on the intensity of immunity of cows to necrobacteriosis, and seroconversion to staphylococcosis and streptococcosis.

As can be seen from the presented data, in the experimental group No. 2, when using the vaccine "Nekovak" together with a plant-tissue preparation "Vidoral" postvaccinal antibodies to Fusobacterium necrophorum increased by $6 \log _{2}$, in addition, due to seroconversion and increased nonspecific resistance, in the experimental group $\log _{2}$ antibody titers to Staphylococcus epidermidis and $5 \log _{2}$ to Streptococcus zooepidemicus increased by $6 \log 2$ Streptococcus zooepidemicus, while in the control group the titers remained unchanged. It can be argued that "Vidoral" stimulates humoral immunity [2], which results in an increase in the production of antibodies, including post-vaccination 
ones. Thus, the use of the vaccine "Nekovak" together with a plant-tissue preparation "Vidoralincreases the protective effect of the vaccine.

No complications or side effects were found with the use of neutral anolyte (ANK+) aerosols.

\section{Conclusions}

Neutral anolyte (ANK + ) has bactericidal, fungicidal and virucidal effects. $[8,9,10,11,16]$ With aerosol application, it normalizes metabolic and immunometabolic processes in the body of calves, by reducing environmental contamination with pathogenic and conditionally pathogenic microflora, reduces the microbial load on the body of calves and, as a result, increases overall resistance.

When using an aerosol of neutral anolyte $(\mathrm{ANK}+)$ together with a plant-tissue preparation "Vidoral" when vaccinated with a vaccine "Rekovac", postvaccinal antibodies to Fusobacterium necrophorum was grown by $6 \log _{2}$, in addition, at the expense of seroconversion and increase non-specific resistance in the experimental group № $26 \log _{2}$ increased titers of antibodies to Staphylococcus epidermidis and $5 \log _{2}$ to Streptococcus zooepidemicus, while in the control group No. 2 titles have remained unchanged. It can be argued that aerosol application of neutral anolyte (ANK+) together with a plant-tissue preparation "Vidoral" stimulate humoral immunity, which results in an increase in the production of antibodies, including post-vaccination ones. Thus, the use of neutral anolyte $(\mathrm{ANK}+)$ together with a plant-tissue preparation "Vidoral" when vaccinated with a vaccine "Nekovak increases the protective effect of the vaccine.

We recommend aerosol application of neutral anolyte $(\mathrm{ANK}+)$ together with a planttissue preparation "Vidoral" for complex prevention of mixed infection of the respiratory tract and distal extremities of cattle by normalizing metabolic processes and increasing the overall resistance of the animal body.

\section{References}

1. Yu.N. Alyokhin, M.S. Zhukov, A.Yu. Lebedeva, Veterinary medicine, zootechnics and biotechnology, 11, 13-19 (2016)

2. A.D. Alekseyev, O.G. Petrova, Veterinary Medicine and feeding, 3, 8-9 (2017)

3. M.I. Barashkin, O.G. Petrova, Agrarian Bulletin of the Urals, 3(145), 28-31 (2016)

4. D.A. Burova, Ptitsevodstvo, 2, 60-63 (2020)

5. I.A. Bukreev, A.T. Kushnir, I.A.Slivko, et. al., Veterinary Medicine, 9, 41-44 (2015)

6. M.P. Butko, P.A. Popov, S.V. Popov, Lemyaseva et al., Problems of veterinary sanitation, hygiene and ecology, 4 (16), 31-38 (2015)

7. A.A. Evglevsky, E.P. Evglevskaya, I.I. Mikhailova, N.V. Vanina, N.F. Yeryzhenskaya, T.A. Suleymanova, Veterinary pathology, 1, 53-58 (2017)

8. S.F. Kolosova, D.E. Akimbaev, I.V. Kashkarova, T.A. Didenko, Young Scientist, 35 (169), 20-22 (2017)

9. A.S. Krasnoperov, E.M. Maryin, E.A. Zabrodin, M.I. Barashkin, I.M. Milshtein, V.P. Pryanichnikov, N.N. Teterev, BIO-2020, 7(238), 26-33 (2020)

10. N.V. Melnik, A.Ya. Samuilenko, R.N. Melnik, S.A. Grin, V.I. Klyukina et al., Necrobacteriosis of animals. Treatment and prevention, 279 (Krasnodar, KubGAU2018)

11. A.I. Miroshnikova, V.V. Mikhaylenko, I.V. Kireev, et al., Veterinary Doctor, 1, 50-55 
(2016)

12. E.S. Odegov, O.G. Petrova, Disinfection modes for bovine lung diseases, Proceedings of the International Scientific and Practical Conference "Actual problems of conservation and development of biological resources", Yekaterinburg, February2015, 267-269 (2015)

13. O.G. Petrova, M.I. Barashkin, I.M. Milshtein, E.R. Kudryashova, N.I. Kolobkova, Bulletin of Biotechnology, 1 (22), 20 (2020)

14. O.G. Petrova, M.I. Barashkin, V.M. Usevich, I.M. Milshtein, MEDICUS-2020, 6(36), $15-28(2020)$

15. O.G. Petrova, M.I. Barashkin, I.M. Milshtein, S.V. Patrushev, Agrarian Bulletin of the Urals, 12(179), 22-26 (2018)

16. V.M. Usevich, O.G. Petrova, Nauchnye issledovaniya 21 veka - nauchnoe setevoe izdanie, 2, 132-139 (2019) 